\title{
The Elizabethan Church as Restoration: Notes on Richard Hooker's Rhetorical Strategy
}

\author{
RUDOLPH P. ALMASY \\ West Virginia University
}

Cet essai identifie certains moments rhétoriques dans les Lawes de Richard Hooker qui utilisent les différences entre l'Église de Rome et celle d'Angleterre pour associer Genève et Rome et ainsi condamner davantage les Presbytériens anglais. Ces passages présentent également la réforme ecclésiastique anglaise davantage comme une restauration de la Chrétienté apostolique que comme un moyen terme entre Rome et Genève. Les procédés et artifices rhétoriques de Hooker y montrent dans quelle mesure les Lawes, un texte issu principalement de la controverse religieuse, consiste fondamentalement en une performance rhétorique au service des objectifs politiques de Hooker et de ceux de l'Église en place. Un de ces objectifs est le conseil de Hooker de «se préoccuper de son propre état 》 visant à faire taire les oppositions telles que celle des Presbytériens anglais perçus comme une menace bien plus importante que le catholicisme international.

$\mathrm{H}$ elen Wilcox uses the notion of "rhetorical negotiation" to describe sites within texts where writers confront, manage, and otherwise deal with certain issues that are less straightforward than they initially appear. Such rhetorical negotiation creates a textual space that often enables a writer to understand difference and so help shape identity. Negotiations such as these can especially be found in post-1558 Elizabethan texts that reflect a complex religious and political culture as they attempt to confront "ecclesiastical politics" and construct religious identity within competing systems. Rhetorical negotiation enables a writer to engage with the diverse influences, forces, and presences — and the consequent textual ambiguities—within such a culture.

This essay examines five sites of "rhetorical negotiation" in Richard Hooker's Of the Lawes of Ecclesiasicall Politie. In these sites, or textual moments, Hooker deliberately links the Church of Rome and the Church of Geneva for the specific political purpose of enhancing the notion of England's established church as a true visible church. Hooker is not interested in developing the idea of what became known as the via media nature of the Church of England. Rather, he is using these textual moments to further condemn his ecclesiastical opponents, the English 
Presbyterians, and to deal in a certain way with the threat from Rome. Hooker's focus is England's ecclesiastical reformation as a restoration of apostolic Christianity rather than a via media between two extremes. Through these rhetorical negotiations Hooker struggles to suggest how the Church of England should be understood as a legitimate earthly manifestation of the Church of Jesus Christ.

Richard Hooker (1554-1600) intended Of the Lawes of Ecclesiasticall Politie to answer in eight books the fundamental points the English Presbyterians had been making against the Elizabethan Church of England since the appearance in 1572 of An Admonition to the Parliament. Books 1 through 4 appeared in 1593 and Book 5 in 1597. The other books of the Lawes, each incomplete, were published in the seventeenth century. Hooker's rhetorical negotiation with the Church of Rome and the Church of Geneva appears once in each of the first five books of the Lawes and is meant, as this essay argues, to stress difference not with both but chiefly with Geneva. In each instance Hooker gives some textual space to the Church of Rome in service to his main goal which is to condemn the Presbyterians as a greater threat than the papists. Hooker's use of arguments and illustrations reveals his way of thinking rhetorically about opponents. Some might argue that these textual sites reveal his own anxieties - and perhaps the cultural anxieties of the late $1580 \mathrm{os}$ - but principally they reflect the needs of the rhetorical enterprise Hooker had undertaken (with the help of his archbishop, John Whitgift) to defend the established church. This essay speculates on the few moments in Hooker's polemical discourse when he feels compelled to add some discussion about the Church of Rome. If the Lawes is from its inception a work of polemic against English Presbyterians, what type of negotiation is being offered that draws upon the Church of Rome? And does this ploy reveal anything about Hooker's attitude in confronting Rome and in moving toward the concept of via media?

Let us begin with how Hooker constructs his interest in Geneva and Rome in Book 1, for Book 1 establishes a pattern that Hooker uses in Books 2 and 3, somewhat in Book 4 , and in a specific section of Book $5 .^{2}$

In Book 1 , of all the books in the Lawes, we find Hooker at his most philosophical, but also most intently focused on the Presbyterians. Indeed, the Church of Rome does not seem to be much on Hooker's mind. There is a textual moment, however, to which Hooker is led polemically, a moment that requires him to bring Rome into the polemical arena. The Church of Rome appears as Hooker begins to focus on the issues, prevalent in the Reformation, of what is contained in scripture and how scripture is to be used. These are seminal issues he examines throughout the Lawes, and first confronts in chapters 11 and 12 in Book 1. For Hooker, scripture reveals "the 
supernaturall way of salvation."3 But this statement is quickly overshadowed by the more polemical issue of ecclesiastical polity's relationship to scripture that Hooker chooses to explore in answering the Presbyterians. Hooker brings the Church of Rome into Book 1 only when the topic is the nature and use of revelation. He does not spend time elaborating the difference between Rome and England on the way of salvation as one might expect. Rather, he turns to what separates and, as we so often see in the Lawes, to what enables him to demonize. At this particular moment, Hooker finds a way to condemn both Rome and Geneva as embracing extreme positions on revelation, positions that reflect maimed intellectual processes and so have the potential to disrupt the church's presence in the world. Rome's extremism ${ }^{4}$-in believing that God reveals supernatural laws through traditions_-is not dissimilar to Geneva's extremism as found in the works of Hooker's Presbyterian opponents, Thomas Cartwright and Walter Travers. These English Presbyterians argued that an unchangeable polity as authored by God is revealed in scripture.

While Hooker indicates that both Rome and Geneva are aberrations, straying from the path the visible church has been on since its inception, his discourse reveals, not surprisingly, that the greater danger is from Presbyterianism. Note what happens in the textual moment which is chapters 13 and 14 of Book 1-chapters dealing with the purpose of scripture. First, Rome is not demonized as we might expect. Although the intellectual confusion of the Church of Rome is mutedly confronted in chapter 13, Hooker's real interest, as revealed in chapter 14, is how scripture is to be approached in the matter of polity. This matter had been present in the debate on church government and scripture since John Whitgift wrote his Answer in 1572 to the Puritan Admonition which demanded further reformation in the established church along Presbyterian lines. For Hooker, this matter (coupled with the arguments on what is contained or comprehended in scripture) is relevant only to the confrontation with the Presbyterians, and not to the condemnation of Rome's elevation of tradition as divine manifestation. Hooker continues Whitgift's political purpose of marginalizing the Presbyterians.

As the title of chapter 14 indicates, Hooker argues for the "sufficiencie of scripture unto the end for which it was instituted.” That end is salvation, not a blueprint for polity. When the Church of Rome equates traditions as "divine and holye" (I. 129), it joins with Geneva in a tyranny of extremism, which is what truly frightens Richard Hooker and the government he represented. Such extremism had to be confronted rhetorically. In Book 1 the Church of Rome is only brought into the discussion - and then only briefly, which is remarkable in its own right—-to build the case that extremism is something that troubles the visible church every 
once in a while. In Hooker's scheme, the Church of England is to be celebrated for moderation and for manifesting an historical continuity. God guides the visible church in order to avoid extremism.

When Hooker turns in chapter 15 of Book 1 to defining the nature of the visible church, we can surmise that he understands it to be the primary issue, along with the proper use of reason, in these chapters of rhetorical negotiation. Both Rome and Geneva err in failing to see that the visible church is grounded in natural law and upheld by reason. By the time the reader turns to chapter 16 (the concluding chapter of Book 1), the Church of Rome is no longer of interest polemically to Hooker. As the Lawes focuses on obedience and submission on the part of the Presbyterians and their followers, Hooker returns to his emphasis on the dangers of private judgment that "must here submit it selfe to be that way guided, which the publike judgement of the Church hath thought better" (I. 141). The true "opposites" throughout Book 1 (and the whole of the Lawes), despite textual moments that give some space to the Church of Rome, are the Presbyterians. ${ }^{5}$ As I have argued elsewhere, ${ }^{6}$ Hooker's principal interest is a political interest: the higher judgment of the church must silence private fancies, and the only fancies Hooker really deals with are Presbyterian.

The second textual moment is found in Book 2 which covers proofs from Thomas Cartwright on the Presbyterian assertion (it is after all the book's title) "That Scripture is the onely rule of all things which in this life may be done by men." 7 In seven chapters, Hooker exposes his opponent's excessive reliance on scripture and argues for the visible church's authority to interpret scripture and make ecclesiastical laws. Rome is hardly mentioned. As Hooker emphasizes that polity is a product of the human mind and historical development, he contrasts the Church of England's reliance on the light of informed reason with the Presbyterian insistence that in all things the believer goes to scripture. The long chapter 7 is especially forceful in explaining and attacking Cartwright's position which condemns the sufficiency of "the authoritie of a man" to resolve issues of conscience in matters of ecclesiastical polity. Hooker concludes with chapter 8, "A declaration what the truth is in this matter," and it is this final chapter which becomes the textual moment for the Church of Rome finally to make an appearance in Book 2.

As in Book 1, the textual moment enables Hooker to reckon with a powerful issue of the Reformation which, for Hooker, arises when he joins together the light of nature and the light of scripture: how does a church interpret scripture in order to understand God's purposes? In the textual moment, which is chapter 8 , three different positions on scripture are articulated. The Church of England celebrates 
reason and scripture, not as equal sources of truth but with the conviction that each aids the other. As for the Presbyterians, they give to scripture too large a domain: "racking and stretching it further then by [God] was ment" (I.189). Finally, Hooker characterizes the Church of Rome for whom "sacred scripture [is] not to bee so large as it is, nor that God did thereby intend to deliver, as in truth he doth, a full instruction in all things unto salvation necessary" (I. 189). Most of chapter 8 elaborates Hooker's argument against the Presbyterian position, with little attention to the Church of Rome and its diminishment of scripture.

Hooker ignores the dangers to the "tender" minds of his readers that Rome poses as that church limits the value of sacred scripture. Instead Hooker prefers to reinforce one of the themes in the Lawes: Presbyterian "strict opinion" can truly (unlike Rome's) trouble the conscience of one who believes that every action, even to the picking up of a straw, must have scriptural warrant. As Hooker explores in chapter 8 the potential troubles for weak minds, he contrasts the two opinions on scripture. Rome believes scripture alone to be insufficient; as for the other opinion, it has "likewise [gone] unto a daungerous extremitie." Note that Hooker does not name Geneva. There are "two opinions ... concerning sufficiencie of holy scripture, each extremely opposite unto the other, and both repugnant unto truth" (I. 191). Again, both are aberrations within the visible church. Each extreme position comments on the other to underscore the reasonableness or historicity of the Church of England as its religious identity is shaped. What really worries Hooker, however, are the ramifications of the Presbyterian "strict opinion" affecting "the whole course of all mens lives and actions" (I. 191). This position is linked in Hooker's mind (and in the view of the established church) to potential social, political, and ecclesiastical chaos. Rome seems less dangerous to Hooker, politically and socially, because Hooker does not construct the threat from Rome as internal. Hooker concludes his polemical response to the position "That Scripture is the onely rule of all things which in this life may be done by men" by urging only the Presbyterians to reconsider their opinion. Hooker remarks: "I therefore leave it to them selves to consider whether they have in this first poynt or not overshot them selves" (I. 192).

The discursive space within chapter 8 is an important and revealing textual moment. Hooker seized little opportunity here to suggest any middle way. He does take a moment-one moment only_to describe the extreme positions of both Rome and Geneva in regard to scripture, but the content of Book 2 (essentially a text produced by religious controversy) is weighed severely against his English Presbyterian opponents. 
The third textual moment is found early in Book 3 as Hooker argues that the Church of England of the sixteenth century is a true, visible, and sacramental institution, one of many visible churches. Hooker opens this book with a chapter that defines "What the Church is, and in what respect lawes of politie are therunto necessarilye required." The entire book responds to the Presbyterian assertion "that in Scripture there must be of necessitie contained a forme of Church-politie the lawes whereof may in no wise be altered." As he concludes chapter 1 of Book 3, Hooker defines any true visible church as a "societie, that is, a number of men belonging unto some Christian fellowship, the place and limites whereof are certaine” (I.206) and then cites as examples "the Church of Rome, Corinth, Ephesus, England, and

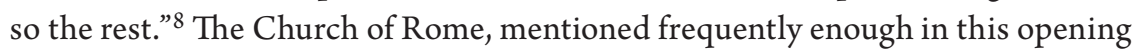
chapter, is a true visible church since its external profession is of one Lord, one faith, and one baptism. The link with biblical churches (Rome included) is a rhetorical gesture to quell the Presbyterian insistence for further reformation in the established Elizabethan Church. The link also implies that England's church is more than just reformed; it is a restoration of an apostolic witness. Hooker's rhetorical strategy demonstrates that, in his discussion of restoration, he is willing to exclude John Calvin's Church of Geneva from the conversation. In other words, not all local representations of the visible church are equal—or at least worth mentioning.

With chapter 1 behind him, Hooker turns to familiar Presbyterian arguments for a particular form of polity and abandons all interest in the Church of Rome. But his use of the Church of Rome in chapter 1 is important. Hooker answers the Presbyterian assertion (the substance of Book 3 ) that "in scripture there must be of necessitie contained a forme of Church-politie.” In answering that assertion, Hooker must define what is understood by the notion of the visible "church of Christ which was from the beginning is and continueth unto the end. Of which Church" by the way, "all parts have not been alwaies equallie sincere and sound" (I. 201).9

When Hooker utters that phrase "all parts have not been alwaies equallie sincere and sound," he chooses not to condemn the Church of Rome as unsound, although he surely could have done so. The textual moment which focuses momentarily on the Church of Rome as a true church leads Hooker here, and in Book 4 as we shall see, to define in natural and political terms what is meant by the visible church, and to identify principles useful in reforming a church which has not always been "sincere and sound." And so the textual moment, as happens elsewhere, enables Hooker to celebrate the historical restoration and the continuity of the Church of England from apostolic times, as well as to link the work of restoration to visible, historical entities like Rome, Alexandria, Ephesus, and Corinth. Geneva doesn't 
warrant being mentioned. Note too that "Rome" could, in the reader's mind, refer to both first century Rome and Renaissance Rome.

The visible church, regardless of where it is manifested, is defined by its sincere efforts to serve God and remain pure while holding fellowship, as God intends, with other churches, even if those churches need reforming. The Church of England can have fellowship with the Church of Rome (and for that matter with the unnamed Church of Geneva) if it believes that by doing so it serves the will of God. The Church of Rome, described in this opening chapter as part of the family of Jesus Christ, ${ }^{10}$ reinforces Hooker's attempt to lead his readers toward a better sense of the nature of the visible church to which they belonged as subjects of Elizabeth I.

Although Hooker begins Book 3 with this discussion of the Church of Rome as part of the Christian family, ${ }^{11}$ he leaps from Rome to the Presbyterians in order to expose Presbyterian extremism. This manoeuvre points to his political agenda and suggests why Geneva should not be named in the list of churches that includes England. The Presbyterians in their polemical enthusiasm make a radical point: neither Rome nor England is a true church, "As there are which make the Church of Rome utterly no Church at all, by reason of so many, so greevous errors in their doctrines: so we have them amongst us, who under pretence of imagined corruptions in our discipline, does give even as hard a judgement of the Church of England it selfe" (I. 202). To further expose dangerous Presbyterian thinking "amongst us," Hooker cites the frequently argued issue of baptizing the infants of papists. He argues that since heretics are part of the visible church and Rome, although heretical, is part of the whole Church of Jesus Christ, the children of the Church of Rome may be baptized in reformed churches. This argument not only reinforces the sense of fellowship within the ongoing visible church, regardless of its unsound parts; it also more importantly shows that, although the textual moment in Book 3 seems to deal with the situation surrounding the Church of Rome, Hooker's polemical mind is always on the Presbyterians. For example, he takes the opportunity here to cite Calvin's Epistle 149 and to condemn Calvin's seemingly "crased” opinion against baptizing the children of papist parents.

This discussion in Book 3 demonstrates that England is a continuation of the apostolic, visible church of first century Christianity. Both Rome and Geneva are aberrations in different ways from this historical path. And so chapter 1 ends with two declarations. First, Hooker portrays the catholic church as "devided into a number of distinct societies, every of which is termed a Church within it selfe" (I. 202). Second, as Hooker continues at chapter's end to see the visible church as "severall societies of Christian men, unto everie of which the name of a Church is 
given," he lists those remarkable examples we have already noted: "the Church of Rome, Corinth, Ephesus, England, and so the rest" (I. 206). Within the polemic which is the Lawes, the absence of Geneva is conspicuous. Here the textual moment that draws attention to the Church of Rome as part of the visible church is intended ultimately to say more about Presbyterianism than papism. The moment calls into question whether Geneva is a legitimate representative of the apostolic church. It might be a Christian fellowship, but not one, like England, with "long experience."

And what is found in Book 4 "Concerning their third assertion, that our forme of Church-politie is corrupted with popish orders rites and ceremonies banished out of certaine reformed Churches whose example therin we ought to have followed"? Since this book explores the Presbyterian complaint that the Church of England is corrupted with popish ceremonies, one might expect some analysis of the Church of Rome and its relationship to England. But Hooker is not interested in defining or discussing the Church of Rome in this book. Indeed, Book 4, despite its title, is not about the "popish orders rites and ceremonies banished out of certaine reformed Churches." Instead, Hooker chooses to discuss the principles used when reforming corruptions that appear from time to time in the visible Church of Jesus Christ. This discussion enables Hooker to condemn the principles embraced by the Presbyterians, especially as they contrast with the more rational and workable ones of the Church of England. Without any reference to Rome, Hooker summarizes the English position in the opening chapter: "The thinges which so long experience of all ages hath confirmed and made profitable, let not us presume to condemne as follies and toyes" (I. 274). As Hooker proceeds in Book 4, he repeatedly emphasizes how impossible the Presbyterian goal is of returning to specific apostolic customs, laws, and ordinances; that is, "to reduce things unto the auncient state wherin at the first they were" (I. 277) in order to create a single, universal, visible church with only one option for polity.

To answer his opponents, Hooker decides to summarize eight main points made by Cartwright, and to answer those arguments by articulating England's position that the Church of England retains from Rome only what is profitable. The rites retained are not intrinsically Church of Rome. Rather, Hooker argues, they are from the visible, universal, and ongoing Church of Jesus Christ. When the opponent urges that all rites retained from Rome must be abolished because they do no good, Hooker deflects the point by accusing his opponents of "strong clamour," of deliberately filling the ears of the people with "general discontentment" against "the lawfull guides and governors of their souls” (I. 285). Concentrating on Presbyterian 
agitation, Hooker chooses to expose Presbyterian extremism and condemn his opponent as dangerous to the church and the state. The question finally is the methodology of reformation, not as England is pitted against Geneva and Rome in fashioning some type of via media, but as the Presbyterian "me thinketh" (a great danger that would produce unacceptable variety) is pitted against "that which the Church [of England] hath received and held so long for good, that which publique approbation hath ratified." England uses ceremonies that the history of the visible church has proved are "godly, comely, decent, profitable" (I. 286).

But even more important is the Church of England's lawful power to make ceremonies for itself. As Hooker reports here and in Book 7: "we lawfully may observe the positive constitutions of our owne Churches, although the same were but yesterday made by our selves alone" (I. 288). However, these ceremonies were not made yesterday, Hooker insists. They return to an earlier "people of God" (a particularly vague phrase), so that Hooker's reader is encouraged to imagine the continuity of the church from apostolic times to the present, a continuity that Geneva seems not to be a part of. Perversions happen, deformities surface, extremism dominates for a moment. That is why, in emphasizing the authority of the Church of England within the English realm to determine its own rites, Hooker can finally say: "Let the Church of Rome be what it will, let them that are of it bee the people of God and our fathers in the Christian faith, or let them be otherwise, hold them for Catholiques or holde them for heretiques, it is not a thing either one way or other in the present question greatly material" (I. 288). And it is the "present question" which controls not only the polemical performance but Hooker's revelation of his positions as he negotiates how to define the Church of England and make vivid what is meant by the concept of a visible Church of Jesus Christ. Amid differing national or regional churches, the fundamental question is how scripture is to be read in determining divine prohibitions concerning "indifferent ceremonies." In identifying the issue this way, Hooker can avoid talk about the nature of the Church of Rome while emphasizing that the Church of England reads God's words as a call for understanding, not for the erecting of partition walls "of difference in such things indifferent" (I. 293). ${ }^{12}$

In chapter 9, Hooker reinforces his position that the Church of England continues on the path that the whole Church of Jesus Christ has always followed. Ancient rites come from - and note Hooker's general language again — "such as were before us" or "our fathers" (I. 302). ${ }^{13}$ Rome is an aberration, but much worse is the Presbyterian aberration because they are within, those "in a fretting mood at the Church of Rome," those with "distempered affections" (I.302). When ecclesiastical problems are internal, 
power and order (that is, the corporate) must solve those problems and thus shape identity. Because they are an internal threat, the Presbyterians are the ones who need to alter their persuasion, need to cease their outrageous charges, need to behave as good citizens. Hooker boldly states: "We hold it better, that the friends and favourers of the Church of Rome should be in some kind of hope to have a corrupt religion restored, then both we and they conceive just feare, least under colour of rooting out Poperie, the most effectuall meanes to beare up the state of religion be remooved, and so a way made eyther for Paganisme, or for extreme barbaritie to enter" (I. 303-304). Where are the exhortations for the papists to reconsider? Nowhere. Hooker asks only the Presbyterians to reexamine their principles.

Hooker comes finally to the last chapter of Book 4: "A declaration of the proceedings of the Church of England for establishment of things as they are." Here is a rich textual moment that captures the main idea of my essay. First, Hooker contrasts his church's guides, "the auncient receaved customes of the whole Church, the universall practices of the people of God, and those very decrees of our fathers" (I. 340), with the opponents' "rash and inconsiderate proceeding" (I. 341). Hooker then reiterates his worry about extremism. The goal of Book 4 has been to demonstrate how the Church of England has followed "reasonable moderation." And this principle, unlike those embraced by Rome and Geneva, has been used throughout the history of the visible church. Geneva is known for "extreme alteration" (I. 342), and Rome maintains "extremely most hurtfull corruptions" (I. 341). ${ }^{14}$ Hooker links them together as deformities to avoid.

This textual moment makes plain that England's "reasonable moderation" is not a negotiation between extremes but the historically responsible way of proceeding. And, fortunately for England, it is also God's way, so Hooker proclaims. Precisely to avoid "desperate extremities," Hooker argues, the "Almightie ... giveth wisedome [to] and inspireth with right understanding" those who direct his church (I. 342). Always within the whole Church of Jesus Christ, but now especially in this specific, historical manifestation which is the Church of England under Elizabeth I, God has used his "provident restrayning hand, to stay those eager affections in some, and to settle their resolution upon a course more calme and moderate" (I. 342). For Hooker, reformation can happen in at least two ways. First, "this moderate kind, which the church of England hath taken," directed as it has been by God. Then a second, "more extreme and rigorous which certaine Churches elsewhere have better liked" (I. 343). Here, Hooker does not even give the Church of Geneva the courtesy of being named. The ploy reflects that earlier dismissal: "The Church of Rome, Corinth, Ephesus, England, and so the rest." 
Although the Church of Rome is mentioned throughout the Lawes, there is only one other discernible textual negotiation where Hooker finds it useful for his polemic to comment on England's relationship to the Church of Rome. ${ }^{15}$ Let us turn briefly to the first ten chapters of Book 5, chapters which serve as an introduction to the several specific issues surrounding the Book of Common Prayer that Hooker includes in this most lengthy book of the Lawes. Hooker's polemical goal is to answer the recurring criticism that the prayer book, to use the phrases found in the title of Book 5, is full of "much superstition" and that the ministry of the church is "corrupt." With slightly more political alarm than we might expect, Hooker hopes to educate his Presbyterian opponents so that contentions in the established church, which he argues can breed atheism, may cease. Zeal (always associated in the Lawes with the Presbyterians) needs to be quieted.

In his opening discussion, particularly on superstition, Hooker does not single out the papists for criticism as one might anticipate. Rather, his eyes remain focused on the Presbyterians, for he continues with the dichotomy we have seen before: the singularity of the Presbyterian pitted against ancient practices of the church which Hooker seems never to associate specifically with the Church of Rome. These opening chapters expose the "irreligious humor" (and political danger) of the opponent ${ }^{16}$ who finds little to embrace in the Church of England: "Allmost whatsoever wee doe in the exercise of our religion accordinge to lawes for that purpose established, all thinges are some waie or other thought faltie, all thinges stained with superstition" (II. 30). Hooker briefly summarizes the Presbyterian position which would be obvious from what has been covered in the earlier books, based as they are on the words of Thomas Cartwright: "shunne conformitie with the Church of Rome;" pattern the Church of England after the first churches to be truly reformed (that is Geneva); and institute only those rites and ceremonies "commanded of God" (II. 32). Hooker prefers "the ancient ordinances rites and longe approved customes of our venerable predecessors" (II. 36-37). But Hooker does not merely prefer. He discusses the method (or kinds of authority) the church follows when determining what is convenient "in the outward publique ordering of Church affaires." In brief, the church follows reason, then ancient practice, and finally its own discretion in determining local ecclesiastical ordinances. Hooker's assumption, not embraced of course by the opponent, is that "the worde of God leaveth the Church to make choice of hir own ordinances" (II. 46). Hooker seeks to stress the authority and the freedom of a national church as a visible manifestation of the whole Church of Jesus Christ. Hooker further stresses the multiple authorities that a national church uses to reform itself. Hooker privileges his national church 
here not to construct any via media, but to contrast internal extremism with reason and ancient practice.

A textual moment occurs when Hooker discusses the "reasonable" principles that the Church of England is authorized to follow. Specifically, within chapter 8 of Book 5, the Church of England's power in relationship to both Rome and Geneva is underscored: "the Church beinge a bodie which dyeth not hath alwaies power, as occasion requireth, no lesse to ordeine that which never was, then to ratifie what hath been before" (II. 38). Within a chapter that strongly praises the power and judgment of the church as manifested in England, Hooker condemns both Geneva and Rome for challenging "the very authoritie of the Church it self" to determine what is fit and convenient: "Our dislike of them, by whome too much heretofore hath bene attributed unto the Church, is grown to an error on the contrarie hand, so that now from the Church of God too much is derogated. By which removall of one extremitie with an other, the world seekinge to procure remedie, hath purchased a meere exchange of the evell which before was felt" (II. 40).

Hooker does not construct the discussion on England's liturgy and ministry, which follows in Book 5, as a negotiation between the practices of Rome and Geneva. Rather, the path followed is the same path the visible church has followed, so Hooker argues, since its beginning in determining what is fit and convenient in worship. The textual moment makes sense at this particular place in these introductory chapters to Book 5 , because it positions Hooker to argue for the expert judgment that the church has used in developing its worship and its ministry as reflected in the Book of Common Prayer.

These textual moments reveal Hooker's consistent attempt to draw his reader's attention to the power and authority of visible, local churches with, of course, the Church of England at the centre of the rhetorical enterprise. The notion of restoration for that Church of England is more important than any sense of a via media, for it is with the notion of restoration that Hooker, following his mentor John Jewel, positions England-as the identity of the Elizabethan church evolves. In exploring these textual moments, one might conclude from the Lawes that Hooker's overriding purpose was to advertise the internal danger to England from the English Presbyterian threat, and to indicate the correct path for England, rather than emphasize difference with the Church of Rome. Certainly this was the understanding of the anonymous writer of A Christian Letter, the first printed response (1599) to Hooker's work. In many places in the Letter, the author argues that Hooker's various doctrinal statements smell of "popish blasphemie" (IV. 7) and "underprop" too many popish principles. In fact the writer wonders whether 
Hooker has been provoked by "our adversaries," the papists, to write as he does, especially against John Calvin (IV. 57).

Did Richard Hooker in fact sympathize with the Church of Rome? One could counter this idea with reference to an early anti-papist sermon of Hooker's, the first sermon on Jude, probably from $1583 .{ }^{17}$ Yet this piece appears more as propaganda rather than a heartfelt sermon. It is as if someone had asked Hooker to write a sermon enthusiastically against the Church of Rome; and he did it on a standard biblical text, using language that was typical, that had been used in describing Roman Catholics since Luther and Tyndale, and expertly exploited by John Jewel. There is little new or interesting in Hooker's sermon. ${ }^{18}$ Furthermore, there is little urgency in the language nor in Hooker's application of the Jude text (verse 18) to papal "mockers in the last time, which should walke after their owne ungodly lusts"; and certainly nothing as urgent as his worries in the Lawes a few years later over Presbyterian lay elders and the Presbyterian elevation of scripture "even so farre as to the taking up of a rush or strawe." It was not unusual for Hooker's enthusiasm to get the better of him during a rhetorical performance, and so it is probably not appropriate to ask whether Hooker really believed, as he wrote in this Jude sermon, that "Pagans and Turkes" were better off spiritually than followers of Rome, or that papists "have smothered every sparke of that heavenly light, they have stifled even their very naturall understanding ... a happy case it had beene for these men if they have never beene borne" (v. 24). Perhaps the Jude sermon is best seen as a piece of propaganda affirming the standard Reformation position that England's is a true church since "Gods blessed sacraments [are] duly administred, his holy word sincerely and daily preached" (v. 35), the mantra of the reformists.

In contrast to the Jude sermon, Hooker composed A Learned Discourse of Justification, Workes, and How the Foundation of Faith is Overthrowne a few years later in 1586. This work tackles "that graund question, which hangeth yet in controversie betwene us and the church of Rome, aboute the matter of justefying righteousnes" (v. 109). A Learned Discourse is generous to Rome, and seizes many opportunities to identify how England “joyne[s] handes with the churche of Rome” (v. 110). Yet the impetus for its creation was not true sympathy with Rome, but rather self-defense over a remark Hooker made during one of his sermons at the Temple Church where he served as Master from 1585 to 1591: "I doubte not but god was mercyfull to save thowsandes of our fathers lyvinge in popishe supersticions in asmuche as they synned ignorauntly" (v. 118). The remark was made much of by Walter Travers, a colleague of Cartwright and a stanch Calvinist Presbyterian, who served under Hooker and became Hooker's adversary until his dismissal from the Temple Church 
in 1587. Hooker takes the opportunity (he calls it "so fitt an occasion as was offred me" [v. 166]) to prove he was right with a composition, or possibly a group of sermons at one time, eloquently and emphatically composed as much to defend himself as to argue that some papists had been, and could be, saved by a merciful God. In some sense A Learned Discourse is a rhetorical performance. Hooker proceeds to prove that Rome "doth not directly deny the foundacion of christianitye" (v. 125) and to defend "that mother sentence, whereof I little thought that so much trooble would have growen" (v. 165). And this is a much different attitude to that revealed in the first Jude sermon.

But finally, like the Lawes, A Learned Discourse is less about Rome (despite its significant textual space in the discourse) and more about internal politics. Hooker has written his discourse for the Temple congregation, hoping that "the thinges them selves which I have spoken unto you ... are sound" even though "some" have given him "injurye" (v. 168). It is the "some," the confused "them," the "ill-disposed," who need to be watched, despite Hooker's forgiveness of their behaviour toward him. ${ }^{19}$ In the Lawes it continues to be the Presbyterians who need to be watched. For finally, those who embrace the Church of England, who are conforming, must turn their eyes within and take care of their own estate. Having proved his case in A Learned Discourse for the saved of the Church of Rome, although not wading in as deeply as he could, so he admits, Hooker now thinks "yt a greate deale meeter for us to have regard to our owne estate, then to sifte over curiouslye what is become of other men" (v. 166).

"To have regard to our owne estate" is an important exhortation. It is the impetus for another piece of writing from Richard Hooker. After Travers was relieved of his duties at the Temple, he wrote A Supplication made to the Privy Counsel for reinstatement. ${ }^{20}$ In his Answer to the Supplication Hooker stresses Travers's challenge to authority, his insubordination, and foremost his audacity to reprove Hooker "openlie, afore all, that other might heare, and feare" (v. 203). Hooker condemns Travers' rhetorical manipulation of the Temple situation: Travers first gives the impression that Hooker was not interested in peace and quietness, and then builds on this impression by exposing Hooker's doctrinal problems so that the Temple congregants could not "choose but be favourablye interteyned" (v. 235). "To have regard to our owne estate" is to silence people like Walter Travers whose example would allow "all men ... [to] think what the liste and speak openly what they thinke" (v. 247). A national church identity cannot be built on such singularity.

As for thinking what they list, different visible churches, congregations of "faythfull men," will interpret adiaphora (things neither required nor prohibited by 
scripture) and polity differently to suit their own estate. Variety then is possible (and acceptable) as God's will is being discerned. That is one of the reasons Rome and Geneva can be considered part of the visible Church of Jesus Christ. Externally, variety may be inevitable; but internally, it could not be tolerated. Aware then of the power of rhetoric and the effectiveness of adversarial polemics in the service of political goals, Hooker's writings can be seen fundamentally as rhetorical performance to silence opposition. His strategy was consistent: attack the Presbyterians, deal with Rome, support the established church for the sake of the nation.

However, the dearth of severe criticism of Rome in the textual moments I have identified in Lawes is not adequate grounds for concluding that Hooker was sympathetic to the cause of Roman Catholicism. One has to be careful in exploiting controversialist texts of the Reformation, and in assuming issues like polity and practice were firmly settled, in any attempt to determine what a rhetorician such as Hooker truly believed. Hooker surely knew about international Catholicism's agitation against England in the 1580 os. This was, after all, the decade of the Armada, of Mary, Queen of Scots, of strong legislation against the Roman Catholics, of the Jesuit mission, of rebellion in Ireland. But Hooker may have felt that these were dangers from beyond, and he, like his Archbishop, wanted to focus on internal dangers, especially when Puritan activity was directed, so it appeared, against conformity and established church order. As Diarmaid MacCulloch reminds us, Archbishop Whitgift's campaign against nonconformists, regardless of the form it had been taking since 1583 , was principally a campaign to "obey superior powers." ${ }^{21}$ Hooker's Lawes conforms perfectly with this campaign, particularly if we keep in mind the strong Presbyterian organization and pressures of the late 1580 s when Hooker was composing his work, the anxiety caused by the Marprelate tracts of 1588 and 1589 which savagely ridiculed and attacked Elizabethan bishops, and finally Richard Bancroft's campaign against the Puritans as Bancroft positioned himself to succeed Whitgift as archbishop. Hooker no doubt saw Presbyterianism as an internal movement, easily leading to separatist fanaticism, as chapter 8 of the Preface to the Lawes suggests. ${ }^{22} \mathrm{He}$ may have viewed Church of Rome activity as a conspiracy involving treason against the Elizabethan state; but with an international locus.

Rome, then, had to be rhetorically negotiated in a text that emerged in the midst of such dangers and which polemically had to lead readers to see the more pressing internal danger that church and state saw in Presbyterianism. This is why moments that give the Church of Rome textual space are so intriguing within the discourse and surely work against the later notion of via media. Certainly they signal the importance of understanding how Hooker's rhetoric plays out as he needed 
to portray the visible Church of England as a true restoration with a legitimate continuity with the past.

\section{NOTES}

1. Helen Wilcox, "She on the hills': Traces of Catholicism in Seventeenth-Century English Protestant Poetry," in The Reformation Unsettled: British Literature and the Question of Religious Identity, 1560-1660, ed. Jan Frans Van Dijkhuizen and Richard Todd (Turnhout: Brepols, 2008), pp. 9-33, 32.

2. Among the few studies of Hooker's attitude toward the Church of Rome, Richard Bauckham's "Hooker, Travers, and the Church of Rome" in Journal of Ecclesiastical History 29 (1978), pp. 37-50 examines Hooker's position on Rome in the 1580 os on the occasion of the controversy with Walter Travers at the Temple. In arguing that in the 158 os Hooker regarded Rome as the chief threat, Bauckham specifically examines the two sermons on Jude to suggest that one cannot read the Hooker/Travers controversy in light of the later Lawes. While I do not agree with Bauckham's conclusions, his essay demonstrates that specific polemic produces texts. This observation is useful in approaching the Lawes.

3. Richard Hooker, Of the Lawes of Ecclesiasticall Politie, gen ed. W. Speed Hill, The Folger Library Edition of the Works of Richard Hooker, vols. I-V (Cambridge: Belknap Press of Harvard University Press, 1977-1990); vols. vi (2 parts) and VII (Binghamton, NY: Center for Medieval and Early Renaissance Studies, 1993-1998), I, 117. All references to Hooker are to this edition with volume and page numbers given in the text.

4. Hooker writes: "When the question therefor is, whether we be now to seeke for any revealed law of God otherwhere then only in the sacred scripture, whether we doe now stand bound in the sight of God to yeeld to traditions urged by the Church of Rome the same obedience and reverence we doe to his written lawe, honoring equallie and adoring both as Divine: our answere is, no" (I. 123).

5. Hooker summarizes the crux of the issue in Book 1, chapter 16: "As that first error sheweth wheron our opposites in this cause have grounded themselves. For as they rightly maintaine, that God must be glorified in all thinges, and that the actions of men cannot tend unto his glorie, unlesse they be framed after his law: So it is their error to thinke that the only law which God hath appointed unto men in that behalfe is the sacred Scripture" (I. 138).

6. See my "Language and Exclusion in the first book of Hooker's Politie," in Richard Hooker and the English Reformation, ed. W.J. Torrance Kirby (Dordrecht, The Netherlands: Kluwer Academic Publishers, 2003), pp. 227-42.

7. Thomas Cartwright (1535-1604) was the leading Presbyterian scholar during Elizabeth's reign. When Whitgift answered An Admonition to the Parliament, Cartwright responded with Replye to an Answer (1573). Whitgift then wrote a defense of his answer which Cartwright attacked in the Second replie agaynst Master Doctor 
Whitgifts second answer, touching the Church discipline (1575). Although Hooker used both replies in identifying Presbyterian complaints against the established church, the Second replie provided most of the material Hooker specifically responded to.

8. One of the few scholars to comment on the phrase "the Church of Rome, Corinth, Ephesus, and England, and so the rest" is William H. Harrison in his essay on "The Church" in the recently published A Companion to Richard Hooker, ed. Torrance Kirby (Leiden: Brill, 2008), pp. 305-336. For Harrison, the list indicates Hooker's acceptance of different visible, organized churches linked to geographical locations - a city state, a territory, or a country, churches "in distinct places and times" p. 305.

9. No doubt Hooker is echoing Church of England Article xIx that reminded Elizabethans that certain churches-Jerusalem, Alexandria, Antioch, and Romehad "erred, not only in their living and maner of ceremonies, but also in matter of fayth.”

10. In his comments on Hooker's position concerning the precise nature of the Church of Rome, Anthony Milton stresses how Hooker refused to speak of Rome as Babylon (the word protestants always associated with Rome) and preferred to see Rome as "essentially an individual church on a par with other churches in God's family." Anthony Milton, Catholic and Reformed: the Roman and Protestant Churches in English Protestant Thought 1600-1640 (Cambridge: Cambridge University Press, 1995), p. 146.

11. Hooker writes: "In like sort with Rome we dare not communicate concerning sundrie hir grosse and greevous abominations, yet touching those maine partes of Christian truth wherein they constantlie still persist, we gladly acknowledge them to be of the familie of Jesus Christ” (I. 202).

12. In citing Ephesians 2.14 in chapter 6 of this book, Hooker takes as the model for unity and understanding Paul's affirmation of what Jesus Christ has accomplished. To quote from the Geneva Bible: "For he is our peace, which hathe made of bothe one, and hathe broken the stoppe of the partition wall."

13. Many readers surely would conclude that "our fathers" were followers of the Church of Rome, but Hooker is careful in his language not to suggest that outright.

14. When Hooker was preparing an answer to A Christian Letter (1599), the first Puritan response to the Lawes, he wrote sarcastically that "two things there are which troble greatly these later times, one that the Church of Rome cannot, another that Geneva will not erre" (IV. 55).

15. Book 8 contains no true textual moment, although Hooker does tentatively link the Presbyterians and the papists since both argue against the ecclesiastical powers given to the English sovereign. Hooker does discuss at length the Church of England's differences with Rome on the meaning of confession and penance in his "Tractate on Penance," which has been traditionally included as part of an allegedly revised Book 6. Some scholars do not consider this inclusion legitimate, and for this reason it is excluded from consideration in this essay. See my "Book vi and the Tractate on Penance: Do They Belong Together?" in Richard Hooker and the English Reformation, 
pp. 263-83. See also W. Speed Hill's remarks on the inclusion of the Tractate on Penance in the Lawes in "Works and Editions II" in Companion to Richard Hooker, pp. 41-49.

16. As Hooker writes in chapter 2 : "Nothinge pleaseth them better, then these manifold oppositions about the matter of religion; as well for that they have hereby the more opportunitie to learne on one side how an other may be oppugned, and so to weaken the creditt of all unto them selves; as also because by this whot pursute of lower controversies amongst men professinge religion and agreinge in the principall foundations thereof, they conceave hope that about the higher principles them selves tyme will cause altercation to grow" (II. 25).

17. See Volume V of the Folger Library Edition for text and commentary on the two Jude sermons, as well for A Learned Discourse of Justification which shall be mentioned next.

18. For example, Church of Rome adherents are fleshly and carnal men, godless persons, enemies of the cross. Their priests are belly creatures, hypocrites, massingpriests. Rome is know for its papal stews, for "mingle mangle of religion and superstitution," for all kinds of abominations.

19. Hooker writes of his Presbyterian opponents: "Whereof I beseeche them, in the meekenes of Christe, that have bene the first original cause, to consider that a watchman maye crye an enemye, when indeed a freend commeth" (v. 169).

20. Travers appealed Archbishop Whitgift's decision to silence him for challenging Hooker by writing A Supplication made to the Privy Counsel. This in turn prompted Master Hookers Answer to the Supplication that Master Travers made to the Counsell which Hooker addressed to Whitgift. Travers' Supplication and Hooker's Answer are both printed in Volume v of the FLE, pp. 171-257. Then follows William P. Haugaard's, “The Hooker-Travers Controversy," pp. 261-97.

21. Diarmaid MacCulloch, The Later Reformation in England 1547-1603 (New York: St. Martin's Press, 1990), p. 48.

22. A useful study of Puritan and papist pressures on Elizabeth's government is Patrick McGrath's Papists and Puritans Under Elizabeth I (London: Blandford Press, 1967). In speaking of the Puritan onslaught, McGrath writes: "In the 1580 os the powerful and organized opposition which threatened the established church appeared at times to be so formidable that it seems remarkable that the church managed to emerge fundamentally unchanged at the end of the decade and to be in a position to launch a vigorous counter-offensive against those who sought to change it" (205). Hooker's Lawes should be seen as part of this counter-offensive. 